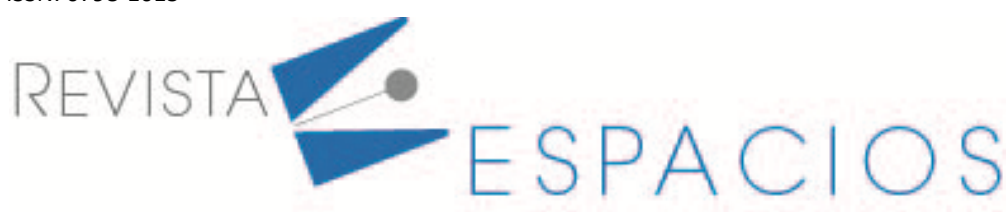

\title{
Relations among social, emotional and moral competencies, reading and mathematical competence in students of secondary education
}

\author{
Las relaciones entre las competencias socioemocionales y morales, lecturas y competencia \\ matemática en estudiantes de educación secundaria
}

\author{
LLORENT, Vicente J. ${ }^{1^{*}}$ \\ CABALLERO-COBOS, María ${ }^{2}$ \\ GARCÍA-CABRERA, María del Mar ${ }^{3}$
}

\begin{abstract}
Resumen
Esta investigación tiene como objetivo estudiar la relación entre las competencias sociales, emocionales y morales, la lectora y la matemática. El estudio es transversal y ex post facto, con una muestra de conveniencia de 209 alumnos de 7ํㅜ curso (1ํ nivel de Educación Secundaria Obligatoria en España) en tres centros educativos. Competencia lectora y matemática no se encontraron diferencias significativas y sí en las competencias sociales, emocionales y morales. La falta de relaciones significativas entre competencias clave tiene implicaciones educativas.

Palabras clave: competencias sociales, emocionales y morales; lectura; competencia matemática; educación obligatoria.
\end{abstract}

\begin{abstract}
This research aims to study the relationship among social, emotional and moral competencies, reading comprehension, and mathematical competence. The study is cross-sectional and ex-post-facto, with a convenience sample of 209 students in 7th grade (1st level of Spanish Compulsory Secondary Education) in three schools. Reading and mathematical competence no significant differences were found with other variables. The data highlights significant differences in social, emotional and moral competencies. The lack of significant relations among the three key competencies has educational implications.

Key words: social, emotional and moral competencies; reading, mathematical competence, compulsory education.
\end{abstract}

\section{Introduction}

The current school systems aim to promote an equitable and quality education, which facilitates long-life learning. In this context, it is essential to improve the key competencies (UNESCO et al., 2016), which traditionally focused on literacy and mathematical competencies. Besides, educating a child implies the comprehensive development of all their competencies, and among them, social and emotional competencies stand out, because

\footnotetext{
${ }^{1}$ Associate Professor. Department of Education, University of Córdoba, Spain. vjllorent@uco.es

${ }^{2}$ Teacher of Secondary Education. Junta de Andalucía, Spain. mcaballer7@yahoo.es

${ }^{3}$ Associate Professor. Department of Education, University of Córdoba, Spain. mmgarcia@uco.es

* Corresponding author
} 
they help to detect, understand and regulate emotions and social relationships, incorporating them appropriately in their lives (Denham, 2006). As Delor's report (1996) already pointed out, the development of social and emotional competencies in education makes young people better prepared in school, work, and in general, in their relationships in society (Hawkins et al., 2008). In this context, it is highlighted the importance of adding the development of social and emotional skills to the traditional basic skills (reading and calculation) as a basis to achieve any others (Roegiers, 2016).

The development of these competencies implies that schools must be able to provide students with the necessary tools, so that they learn to put the knowledge and abilities acquired in the class at the service of action, transferring it to their daily life, and their professional future (Martínez, 2017). As a starting point to achieve this, it is necessary to advance in the knowledge of the interaction between these competencies (Panayiotou et al., 2019).

Among the key competencies, reading literacy stands out. This competence is framed within the literacy competence, which as a whole is made up of four skills: oral comprehension, written comprehension, oral expression and written expression (European Parliament and Council of the European Union, 2006). They include the set of skills necessary to identify, understand, create and interpret opinions, concepts, feelings and facts (Council of European Union, 2018). Written comprehension or reading literacy is defined as the ability of individuals to use texts in a useful way in order to achieve their objectives in the society that surrounds them, developing themselves as individuals and as an interactive member of society.

Understanding a written text is vital to perform a great number of daily tasks, such as interpreting the train schedule adequately, communicating through social networks, or simply reading for pleasure (Abusamra et al., 2010). Such written comprehension is directly related to the individual themself, their intellectual capacities, their personal profile, as well as to other variables such as socialization, social intelligence or executive intelligence (Blair \& Razza, 2007). Elements such as adequate self-confidence or self-control directly influence one's understanding of what is reading (Cabero-Almenara et al., 2018), since, like any other human activity, reading is not exempt from emotional assessment (Llorent \& González-Gómez, 2020). Tolerance to distress is also among the factors of an emotional nature that seem to influence reading comprehension. The results of the study carried out by Andrés et al., (2017) with students between 9 and 11 years of age showed that tolerance to distress was a significant predictor in reading comprehension of expository texts. On the other hand, variables such as intrinsic motivation or expectations have also been linked to reading performance (Puccioni, 2015). Another factor that appears to be related to reading competence is social competence. Having found activation in the same areas of the brain during the processes of social perception and reading comprehension could indicate that social perception can be a predictor of reading comprehension (Lehne et al., 2015).

With regard to mathematical competence, this is also considered one of the key pillars of education. It is defined as the set of knowledge and abilities to develop and apply mathematical thinking in everyday situations (European Parliament and Council of the European Union, 2006). Its evaluation is based on the analysis of aspects concerning the organization, understanding and the interpretation of information. It is also related to the ability to pose, express and solve problems. Therefore, this competence is based on the ability to analyze and understand situations, identify the mathematical concepts and procedures that can be used when solving a certain problem, and reasoning appropriately to generate and apply effective solutions.

Among the factors that may be related to mathematical competence are also social and emotional competencies, since the adequate motivation is necessary for the regulation of cognitive and metacognitive strategies that significant mathematical learning requires (Parhiala, 2018). Numerous previous studies have related school performance and affective-motivational factors, focusing mainly on how these variables determine academic performance (Hintsanen et al., 2012). Although many studies have highlighted their connection (López-González 
\& Oriol, 2016), the specific relationship between social and emotional competencies and mathematical competence does not present homogeneous results. On the one hand, there are studies that refer to a positive relationship between motivation towards learning and mathematical performance (Suárez-Álvarez, et al., 2014), highlighting the impact that emotional ability has on this competence since mathematical learning seems to be particularly affected by the emotions of the students (Hanin \& Nieuwenhoven, 2016). However, other recent studies do not find a clear relationship that indicates a causal relationship between positive emotions and results in mathematical learning (Villavicencio \& Bernardo, 2016), or a relationship between self-perceived social and emotional competencies and performance in mathematics (Oberle et al., 2014).

Social and emotional competencies include a set of skills that allows to cope with knowledge, capabilities and attitudes to achieve various personal and interpersonal tasks with quality and success (Bisquerra \& Pérez, 2007). They encompass the ability to manage emotions and social interactions in a way that simultaneously benefits oneself and others (Hawkins et al., 2015). They can be considered as the process through which children and adults understand and control emotions and behaviors by making responsible decisions and consequently, establishing positive relationships in all environments (Durlak et al., 2011).

In the educational context, the Organisation for Economic Co-operation and Development (OECD, 2015) has identified social and emotional competencies as essential for learning in the 21st century. They include personal aspects related to self-awareness, self-control and motivation, social awareness and prosocial behavior, and responsible decision-making (Zych et al., 2018a). In the school environment, these competencies are related to cooperation between peers and, in general, to positive social functioning in the classroom (Roseth et al., 2008). In this sense, empathy (Llorent et al., 2020), as well as the moral aspect (Zych et al., 2019) are added. Both are expressed through social and emotional responses related to moral values (Haidt, 2003) because people tend to feel proud and satisfied when their behaviors are socially and morally consistent, which in turn encourages and predisposes towards such prosocial behaviors in the classroom (Tangney, 1991).

Different investigations have also highlighted the impact of social and emotional competencies on school learning (López-González \& Oriol, 2016). Many find a clear relationship between the aspects of these competencies and academic performance (Llorent et al., 2020) with a clear positive relationship between both (Seider et al., 2013). In this line, the meta-analysis carried out by Durlak et al., (2011), where 213 experimental studies were reviewed on the SEL programs, showed that the quality of social and emotional competencies was positively related to self-concept, sense of belonging to the school and behavior within the classroom. Likewise, it has also been linked to fewer behavior problems, less stress, and better academic results (Sklad et al., 2012). According to Farrington et al., (2012), "non-cognitive" academic factors, such as perseverance, learning strategies and social and emotional competencies positively affect the success of students in school. In this sense, Izard and his colleagues (2001) report longitudinal associations between the knowledge of their own emotions in young children and subsequent academic competence, even after controlling other factors such as age, verbal ability or temperament (Trentacosta and Izard, 2007). In this line, the studies by Stevens et al. (2006) analyzed cognitive, motivational and emotional variables in relation to academic performance in mathematics through the achievement in two tasks, finding that previous results presented a positive association with self-efficacy, self-perception and performance in mathematics. However, this association between self-efficacy and performance turned out to be small. These results were replicated by the study by Cueli et al., (2014) in 626 students (10-13 years old), also finding that previous performance predicted the levels of affective-motivational variables. However, self-perception of their own social and emotional competencies was not related to subsequent outcomes on math tasks.

From the studies analyzed so far, it has not been possible to define accurately the role that social and emotional competencies play in the performance of secondary education students, since the results obtained are diverse 
(Jiménez-Morales \& López-Zafra, 2013). On one hand, some studies find that a higher significant social and emotional development favors a better coexistence, improving individual well-being and learning (Nasaescu et al., 2018). On the other hand, some investigations find a relationship only with some factors of social and emotional competencies (Ghabanchi \& Rastegar, 2014), or with some other different aspects such as cognitive variables (Wu et al., 2019).

Regarding the relationship between sex and key competencies, studies also offer quite varied results. Along these lines there are studies in which women achieve better results in reading comprehension (Llorent \& GonzálezGómez, 2020) and a higher academic performance in mathematics (Cerda \& Vera, 2019). On the contrary, in other studies, it is men who appear to be more competent. The research carried out by Bar-On et al. (2000) finds that men have more social and emotional abilities since they could control impulses and have a higher tolerance to stress. In favor of men, statistically significant differences have also been found concerning reading (Loveless, 2015) and mathematical competence (Marks, 2008). However, the third group of studies did not find gender differences, finding a homogeneous performance between both groups (Rosselli et al., 2006; Arán-Filippetti, \& López, 2016). In the case of women, there is research that finds a favorable result in social and emotional competence, indicating that they have a greater capacity to perceive their own emotions, understand and express them, and in general, to be more aware of what they feel (Palomera et al., 2006). For its part, the study by Sandstrom and Cillessen, 2003 reports more social and emotionally competent behaviors in girls compared to boys, with more empathic concern and higher scores in self-report measures (Charbonneau \& Nicol, 2002; Eisenberg et al., 2007).

On the other hand, the ethnic-cultural group could also be an important variable in the disparity of the different key competencies. That it is shown in relation to school success (Cvencek et al., 2018; Masud et al., 2019), social and emotional competencies (Kuo et al., 2020), reading comprehension (Sewasew \& Koester, 2019), and mathematical competence (Assari et al., 2020; Kalaycioglu, 2015).

In recent years, a new line of research has the goal of clarifying the interrelation between the different key competencies through the study of other associated variables (Panayiotou, Humphrey \& Wigelsworth, 2019). In this context, the most current research is providing new data on the relationship between social and emotional skills, reading comprehension and mathematical competence, although new studies are needed to analyze the possible interaction between these skills. Therefore, this study sets out the objective of analyzing the relationship between the three mentioned key competencies and examining the relationship with personal and school variables such as sex, school and the ethnic-cultural group.

\section{Methodology}

\subsection{Participants}

The total sample of participants is made up of students from all $7^{\text {th }}$ grade $\left(1^{\text {st }}\right.$ Compulsory Secondary Education in Spain) groups in the three public schools in a town in the province of Córdoba, with a total of 209 adolescents $\left(\mathrm{M}_{\mathrm{age}}=12.18, \mathrm{SD}=, 446\right.$, with a range of 11 to 14 years old $)$, of which $108(51.7 \%)$ are girls and $95(45.4 \%)$ are boys; $2.9 \%$ did not answer that question. The number of students according to the school of origin is distributed as follows: School 1 has a total of 72 subjects (34.4\%), School 2 of 58 (27.8\%), and School 3 a total 79 (37.8\%). Depending on the country of origin of the parents and those who self-identified as belonging to the gipsy ethnic group, an ethnic-cultural minority group of 11 subjects (5.3\%) was created; the rest were considered as the ethnic-cultural majority 189 (90.4\%), leaving 9 students (4.3\%) ungrouped due to lack of response. 


\subsection{Design and procedure}

The study is cross-sectional, and ex post facto, with a sample for convenience. Data collection was carried out at the beginning of the first quarter of the 2016-17 academic year. After contacting the management team of the school to request their collaboration, they were informed of the study in question, explained the objective of the research, the characteristics of the tests and that the data obtained would be used only for scientific purposes, respecting anonymity at all times. The application of the tests had the collaboration of the teachers and tutors of each group. Finally, the students were informed, and during several ordinary class sessions, the data was collected.

\subsection{Instruments}

Data collection was performed using two instruments: a questionnaire and an exam with two tests (reading and mathematics). The questionnaire is made up of a first part that collects information on the students' sociodemographic data (sex, school and ethnic-cultural group), and a second part focused on social, emotional and moral competencies, for which the Social and Emotional Competencies Questionnaire, the Basic Empathy Scale and the Scale of Moral Emotions are used. These are scales with 5-point Likert-type responses ranging from 1 (strongly disagree) to 5 (strongly agree).

The Social and Emotional Competencies Questionnaire (Zych et al., 2018b) presents a total of 16 items divided into four factors: Self-awareness (items 1-4, $\alpha=.61, \Omega=.59$ ), Self-management and Motivation (items 5-7, $\alpha=$ $.70, \Omega=.63$ ), Social Awareness and Prosocial Behavior (items 8-13, $\alpha=.72, \Omega=.76$ ) and Responsible Decision Making (items $14-16, \alpha=.63, \Omega=.58$ ). The internal consistency of this questionnaire in this study is very good ( $\alpha$ $=.85, \Omega=.85$ ).

The Basic Empathy Scale (Jolliffe \& Farrington, 2006) is made up of 20 items divided into two factors: Affective Empathy $(\alpha=.80, \Omega=.81$ ) and Cognitive Empathy $(\alpha=.77, \Omega=.78)$. The reliability of the scale is high $(\alpha=.85, \Omega$ $=.85)$.

The Moral Emotions scale (Álamo, Zych, Nasaescu \& Llorent, 2020) is made up of 5 items and has a high reliability $(\alpha=.89, \Omega=.89)$.

The exam with the two tests released by PISA (Program for International Student Assessment) proposes an evaluation framework based on the measurement of the knowledge and skills of the students. These tests assess the development of students' competencies through their ability to extrapolate what they have learnt in school to real-life situations, evaluating students' knowledge to solve daily tasks (OECD, 2016).

Each released test consists of a text and/or common image followed by one or more questions. Student performance is estimated through the tasks that are successfully overcome. This means that the students who are located at a certain level of the performance scale can successfully complete tasks of this level of performance or easier tasks. On the contrary, they are unlikely to solve problems associated with difficulty levels above their position on the performance scale. The relative difficulty of the activities is established through the proportion of the participating students who have solved them correctly. In turn, relative personal competence is estimated through the proportion of the questions that have been answered correctly (OECD, 2003).

Regarding the age of use of the PISA resources, although they were initially designed to be applied to 15-yearold students, the tests released within the area of Literacy can be used at any level of Compulsory Secondary Education. In this research, the test entitled Lake Chad has been used to assess the literacy competence in the $7^{\text {th }}$ grade $\left(1^{\text {st }}\right.$ grade of Compulsory Secondary Education in Spain). The test chosen for the mathematical 
competence was the one called Chat, which is part of the PISA released tests recommended for any level of ESO, and specifically within the arithmetic and algebra stimuli (OECD, 2003).

\subsection{Data analysis}

The reliability analysis of the scales was carried out with the Factor 10.10 software, to calculate the Cronbach's alpha $(\alpha)$ and omega $(\Omega)$ indices. A descriptive analysis of the students was carried out in terms of sex, school and ethnic-cultural group. Pearson's bivariate linear correlation was used to analyze the correlation among social, emotional and moral competencies, including their factors, reading comprehension and mathematical competence. The comparison between boys and girls in all competencies was calculated with the t-Student test. Finally, the different variables of the three schools have been compared with the ANOVA test of one factor or ANOVA of Welch, according to the homogeneity of the variance calculated with the Levene test. After this test, the Games-Howell or Bonferroni post-hoc tests were selected. The analyzes were carried out using SPSS 25.

\section{Results}

The relation of the different competencies and their factors with the socio-demographic variables (age, sex, school and ethinic-cultural diversity) were analyzed. Sex differences in social, emotional and moral competencies, reading comprehension and mathematical competence were studied. As can be seen in Table 1, there are no significant differences by sex.

Table 1

Differences in social, emotional and moral competencies, reading comprehension and mathematical competence according to sex.

\begin{tabular}{lccc} 
& Girls & Boys & $\boldsymbol{t}_{(\mathbf{2 0 1})}{ }^{*}$ \\
\hline Self-awareness & $16.06(2.47)$ & $16.19(2.49)$ & 0.37 \\
\hline Self-management & $11.98(2.57)$ & $12.33(2.41)$ & 0.96 \\
\hline Social awareness and prosocial behavior & $23.10(3.22)$ & $23.45(3.28)$ & 0.73 \\
\hline Decision making & $10.81(2.60)$ & $10.38(2.38)$ & -1.18 \\
\hline Social and emotional competencies & $62.29(7.86)$ & $62.71(7.35)$ & 0.36 \\
\hline Affective empathy & $37.33(7.37)$ & $37.66(6.90)$ & 0.31 \\
\hline Cognitive empathy & $34.49(4.75)$ & $34.54(4.49)$ & 0.07 \\
\hline Empathy & $71.55(10,63)$ & $71.92(9,19)$ & 0.24 \\
\hline Moral emotions & $21.72(3.89)$ & $21,61(3.59)$ & -0.20 \\
\hline Reading comprehension & $1.95(1.12)$ & $2.00(1.15)$ & -0.29 \\
\hline Mathematical competence & $.44(.66)$ & $.55(.68)$ & -1.19 \\
\hline
\end{tabular}

*In all cases $p>.05$

In addition, the same variables were analyzed considering the students' school (see table 2), where School 1 gets a higher score than School 2 and School 3 in self-awareness, social awareness and prosocial behavior, decision making, and the total of social and emotional competencies. Also, there are differences in affective empathy, where School 2 scores higher than School 3, and in moral emotions, where School 1 scores higher than School 3. Global empathy shows differences among schools, but a more in-depth analysis with the post-hoc tests does not identify specific differences by pairs of schools. 
Table 2

Differences in social, emotional and moral competencies, reading comprehension and mathematical competence according to the school.

\begin{tabular}{|c|c|c|c|c|c|c|}
\hline & School 1 & School 2 & School 3 & $F_{(2,206)}$ & $p$ & $\begin{array}{l}\text { Post-hoc } \\
\text { comparisons }\end{array}$ \\
\hline Self-awareness & 17.52 & 15.32 & 15.52 & $17.91^{\mathrm{a}}$ & $<.001^{*}$ & $1-2,1-3$ \\
\hline Self-management & 12.46 & 12.00 & 12.07 & 0.64 & .53 & \\
\hline $\begin{array}{l}\text { Social awareness and prosocial } \\
\text { behavior }\end{array}$ & 24.31 & 22.88 & 22.74 & 4.83 & $.01^{*}$ & $1-2,1-3$ \\
\hline Decision making & 11.47 & 10.00 & 10.40 & 6.22 & $<.01^{*}$ & $1-2,1-3$ \\
\hline $\begin{array}{l}\text { Social and emotional } \\
\text { competencies }\end{array}$ & 66.13 & 60.45 & 61.06 & 9.97 & $<.001^{*}$ & $1-2,1-3$ \\
\hline Affective empathy & 37.78 & 39.74 & 36.18 & 3.95 & $.03 *$ & $2-3$ \\
\hline Cognitive empathy & 35.69 & 33.72 & 34.30 & 2.71 & .06 & \\
\hline Empathy & 73.37 & 73.71 & 69.48 & 3.67 & $.04^{*}$ & - \\
\hline Moral emotions & 22.62 & 21.57 & 21.04 & 3.18 & $.04^{*}$ & $1-3$ \\
\hline Reading comprehension & 1.92 & 1.83 & 2.20 & 2.22 & .13 & \\
\hline Mathematical competence & .40 & .48 & .61 & 1.70 & .18 & \\
\hline
\end{tabular}

The scores of the variables mentioned were analyzed according to the ethnic-cultural diversity of the students, where no significant differences were found between the majority and the minority.

Table 3

Differences in social, emotional and moral competencies, reading comprehension and mathematical competence according to membership in the ethnic-cultural group.

\begin{tabular}{lcccc} 
& Majority & Minority & $\boldsymbol{t}_{(\mathbf{2 0 6})}$ & $\boldsymbol{p}$ \\
\hline Self-awareness & 16.04 & 16.50 & -0.422 & .674 \\
\hline Self-management & 12.13 & 12.33 & -0.194 & .846 \\
\hline Social awareness and prosocial behavior & 23.19 & 24.50 & -0.969 & .334 \\
\hline Decision making & 10.61 & 9.20 & 1.260 & .209 \\
\hline Social and emotional competencies & 62.35 & 62.80 & -0.131 & .896 \\
\hline Affective empathy & 37.49 & 39.67 & -0.731 & .466 \\
\hline Cognitive empathy & 34.42 & 37.00 & -1.251 & .213 \\
\hline Empathy & 71.55 & 78.60 & -1.593 & .113 \\
\hline Moral emotions & 21.56 & 22.00 & -0.283 & .778 \\
\hline Reading ccomprehension & 1.97 & 2.33 & -0.785 & .433 \\
\hline Mathematical competence & 0.48 & 1.00 & -1.902 & .059 \\
\hline
\end{tabular}

In order to identify the relationship among competencies, the correlations were run for social, emotional and moral competencies, and all its factors, reading comprehension and mathematical competence. Table 4 shows 
that there are significant correlations between the factors and the global social and emotional competencies, global empathy and its factors, and moral emotions. On the other hand, reading comprehension and mathematical competence do not correlate with any of the variables or their study factors.

\section{Table 4}

Correlation between social, emotional and moral competencies, and all its factors, with reading comprehension and mathematical competence.

$\begin{array}{lllllllll}1 . & 2 . & 3 . & 4 . & 5 . & 6 . & 7 . & 8 . & 9 .\end{array}$

\begin{tabular}{|c|c|c|c|c|c|c|c|c|c|c|}
\hline \multicolumn{11}{|l|}{ Self-awareness } \\
\hline Self-management & $.367^{* *}$ & & & & & & & & & \\
\hline $\begin{array}{l}\text { Social awareness and prosocial } \\
\text { behavior }\end{array}$ & $.399 * *$ & $.353^{* *}$ & & & & & & & & \\
\hline Decision making & $.314^{* *}$ & $.323^{* *}$ & $.399 * *$ & & & & & & & \\
\hline $\begin{array}{l}\text { Social and emotional } \\
\text { competencies }\end{array}$ & $.727^{* *}$ & $.705^{* *}$ & $.770 * *$ & $.674^{* *}$ & & & & & & \\
\hline Affective empathy & $.263^{* *}$ & .050 & $.278 * *$ & $.153^{*}$ & $.201^{* *}$ & & & & & \\
\hline Cognitive empathy & $.335^{* *}$ & $.266 * *$ & $.426 * *$ & $.242 * *$ & $.438 * *$ & $.376^{* *}$ & & & & \\
\hline Empathy & $.367^{* *}$ & $.178^{*}$ & $.411^{* *}$ & $.208^{* *}$ & $.349 * *$ & $.445^{* *}$ & $.741^{* *}$ & & & \\
\hline Moral Emotions & $.297^{* *}$ & $.246 * *$ & $.421 * *$ & .104 & $.401 * *$ & $.326^{* *}$ & $.427^{* *}$ & $.445^{* *}$ & & \\
\hline Reading Comprehension & -.089 & -.042 & .045 & .047 & .020 & -.045 & .025 & -.028 & -.036 & \\
\hline Mathematical Competence & .039 & .105 & .071 & .068 & .093 & .027 & .092 & .085 & -.085 & .113 \\
\hline
\end{tabular}

\section{Discussion}

The objective of this study has been to deepen in the analysis of the relationship between key competencies, specifically social, emotional and moral competencies, literacy (reading comprehension) and mathematical competence, assessing the role of socio-demographic variables.

Regarding the interaction between social, emotional and moral competencies, reading comprehension and mathematical competence, regardless of the students' sex, as in previous research (Ghabanchi \& Rategar, 2014; Panayiotou et al., 2019), there does not seem be a relationship between any of these competencies. The global results, in line with previous studies (Mavroveli et al., 2009; Aguirre et al., 2019) also do not show any correlation with the different factors, confirming an absence of relationship between perceived social, emotional and moral competences and the traditional academic competences. This lack of relationship could be because students of this age do not usually have a good knowledge of themselves (self-knowledge), derived from an unreal perception of their own abilities.

Likewise, in relation to self-management, understood as self-control and self-regulation, both under normal learning conditions and under stress, in the present study, no relationship was found with reading and mathematical competencies. In this sense, the study by Stevens et al., (2006) also found no significant association between performance and variables such as anxiety. These results differ substantially from those provided by other studies (Walshaw \& Brown, 2012), which have shown that variables such as anxiety, motivation, or the perception of their own competence influence the subsequent academic results. In general, it can be concluded that the presence of negative attitudes does not necessary condition the performance in mathematics, in such a 
way that a student with low motivation or who perceives little utility in mathematics will not necessarily have a low outcome.

Regarding social and emotional competences, in our study, no relationship was found either between prosocial attitudes, prosocial behavior, empathy and academic performance. The data found confirm the study by Oberle et al., (2014) in which the social responsibility of the students was not a predictor of performance in mathematical competence. These results could not be explained in principle by the interaction in learning of both, the attitude of the teacher and the student, since in theory the children perceived by their teachers with less success and academic productivity could present fewer strategies to manage their emotions and have greater difficulties regulating learning behaviors in the classroom (Howse et al., 2003). Therefore, developing more positive interactions would lead to greater academic success and productivity (Graziano et al., 2007). The instruction of social and emotional competencies in a positive learning environment can improve school-related attitudes (Hattie, 2008; Hattie and Yates, 2013), increasing the sense of connection, the student's well-being (Ferragut \& Fierro, 2012) or their degree of involvement in school activities (Dehyadegary et al., 2012). However, a cooperative and emotionally stimulating environment does not seem to indicate that the student has greater literacy or mathematical competencies. Probably, teachers are the key to promote that environment, which opens new research lines.

On the other hand, this apparent absence of a relationship could be due, as suggested by Mavroveli et al., (2009), to the multifactorial nature of learning, which may be influenced not only by social and emotional variables but also by third variables related to the socioeconomic status (Gumora \& Arsenio, 2002) or even personality traits (Ivcevic \& Brackett, 2014). In this sense, recent studies provide new data on the subject by analyzing the indirect effects on the academic performance of the school connection and mental health difficulties. Findings, on the one hand, that social, emotional and moral competencies did not predict achievement in other areas and, on the other, that mental health difficulties were the only statistically significant mediator (Panayiotou, Humphrey \& Wigelsworth, 2019; Howse et al., 2003).

Other factors that may justify the result of our study are behavioral and cognitive variables (Caballero, 2017, 2019; Miñano \& Castejón, 2011), such as intelligence and executive functions (Graziano et al., 2007). Among these variables we can find attention capacity (Tentracosta \& Izard, 2007), self-regulation (Bull \& Lee, 2014) and metacognition (Maná, 2014; Wu et al., 2019). Along these lines, the absence of a relationship in our study between social, emotional and moral competencies, reading literacy and mathematical competence, could be related to the strategies used by the reader to understand and regulate the processes that underlie reading comprehension and mathematical reasoning. That is, executive functions, since there seem to be clear relationships between linguistic and mathematical domains, possibly mediated by their basic dependence on these functions (Blair \& Razza, 2007).

The second of our objectives is to advance in the study of the relation between the previous competencies with socio-demographic variables. In our case, as in the studies by Rosselli et al., (2006); Arán-Filippetti and López, 2016), we did not find significant differences between boys and girls that suggest the need to carry out a differential education in terms of social and emotional strategies related to reading or mathematical competence. On the other hand, regarding the influence of the ethnic-cultural group, unlike in previous studies (Kalaycioglu, 2015; Sewasew \& Koester, 2019; Kuo et al., 2020; Assari et al., 2020) there have not been found differences in the analyzed competences. The reason may be due to the size of the sample of this subgroup of students, which being small does not allow valid conclusions to be reached. Also, the age of the students could influence in the development of the key competencies.

Despite the interesting results, this study has its limitations. The sample size is not large, and the type of sampling does not allow generalizations. Taking into account the above considerations, the limitations of this study, and 
despite the fact that current evidence seems to tell us that social and emotional learning leads to improvements in academic outcomes, our understanding of how and why it occurs has yet to be clarified.

Hence, the need to deepen in the study of this relationship associated with performing specific reading comprehension tasks and solving mathematical problems. Moreover, it should be considered that although many studies find a direct relationship between them, it does not seem to be clear if it is determined by previous performance and the perception of self-efficacy (Cueli et al., 2014) or if it is independent of social and emotional competencies.

The lack of a significant relationship found in this study among the three key competencies has clear implications for educational policy, the academic curriculum, didactic planning, and school practice. On the one hand, it is necessary to continue studying other variables that may be significant for understanding the relationship between these key competencies, carrying out future research that incorporates variables such as executive functions. Finally, according to the results, it seems clear the need to pay attention and dedication to each of the competencies independently and exclusively, to enhance their development and facilitate a comprehensive education of individuals and inclusive schools.

\section{Referencias bibliográficas}

Abusamra, V., Ferreres, Aldo, Raiter, Andrea, De-Beni, Rosana y Cornoldi, César. (2010). Test Leer para Comprender TLC. Evaluación de la comprensión de textos. Buenos Aires: Paidós.

Aguirre, I., Rodríguez-Fernández, A., \& Revuelta, L. (2019). El impacto del apoyo social y la inteligencia emocional percibida sobre el rendimiento académico en Educación Secundaria. European Journal of Investigation in Health, Psychology and Education, 9(2), 109-118.

Álamo, M., Llorent, V. J., Nasaescu, E. y Zych, I. (2020). Validación de la Escala de Emociones Morales en Adolescentes. En V. Llorent y V. Cobano-Delgado. (Dir. y Ed.), Congreso Internacional de Transferencia de Conocimientos y Sensibilización Social "Islam y paz a través de voces musulmanas". Universidad de Sevilla.

Andrés, M., Stelzer, F., Vernucci, S., Canet Juric, L., Galli, J. \& Navarro Guzmán, J. (2017). Regulación emocional y habilidades académicas: relación en niños de 9 a 11 años de edad. SUMA PSICOLÓGICA, 24, 79-86.

Arán-Filippetti, V. y López, M.B. (2016). Predictores de la Comprensión Lectora en Niños y Adolescentes: El papel de la Edad, el Sexo y las Funciones Ejecutivas. Cuadernos de Neuropsicología, 10 (1), 23-44.

Assari, S., Boyce, S., Bazargan, M., \& Caldwell, C. H. (2020). Mathematical performance of American youth: diminished returns of educational attainment of Asian-American parents. Education Sciences, 10(2), 32.

Bar-On, F., Brown, J. M., Kirkcaldy, B., \& Thome, E. (2000). Emotional expression and implications for occupational stress; an application of the Emotional Quotient Inventory (EQ-I). Personality and Individual Differences, 28(6), 1107-1118.

Bisquerra, R., \& Pérez, N. (2007). Las competencias emocionales. Educación XXI, 10, 61-82.

Blair, C., \& Razza, R. P. (2007). Relating effortful control, executive function, and false belief understanding to emerging math and literacy ability in Kindergarten. Child Development. 78, 647-663.

Bull, R., \& Lee, K. (2014). Executive functioning and mathematics achievement. Child Development Perspectives, 8(1), 36-41.

Caballero, M. (2017). Neuroeducación de profesores y para profesores. Ediciones Pirámide. Madrid. 
Caballero, M. (2019). Neuroeducación en el currículo. Ediciones Pirámide. Madrid

Cabero-Almenara, J., Piñero, R., y Reyes Rebollo, M. M. (2018). Material educativo multimedia para el aumento de estrategias metacognitivas de comprensión lectora. Perfiles educativos, 40(159), 144-159.

Cerda, G. \& Vera, A. V. (2019). Rendimiento en matemáticas: Rol de distintas variables cognitivas y emocionales, su efecto diferencial en función del sexo de los estudiantes en contextos vulnerables. Revista Complutense de Educacion, 30(2), 331.

Charbonneau, D., \& Nicol, A. A. (2002). Emotional intelligence and leadership in adolescents. Personality and Individual Differences, 33(7), 1101-1113.

Council of European Union (2018). Council Recommendation of 22 May 2018 on key for lifelong learning. Official Journal of the European Union. Retrieved from https://eur-lex.europa.eu/legalcontent/EN/TXT/?uri=uriserv\%3AOJ.C_.2018.189.01.0001.01.ENG

Cueli, M., González-Castro, P., Álvarez, L., García, T., \& González-Pienda, J. A. (2014). Variables afectivomotivacionales y rendimiento en matemáticas: Un análisis bidireccional. Revista Mexicana de Psicología, 31(2), 153-163.

Cvencek, D., Fryberg, S. A., Covarrubias, R., \& Meltzoff, A. N. (2018). Self-concepts, self-esteem, and academic achievement of minority and majority North American elementary school children. Child development, 89(4), 1099-1109.

Dehyadegary, E., Divsalar, K., Shahsavari, F.P., Nekouei, S., \& Sadr, A.J. (2012). Academic engagement as a mediator in relationships between emotional intelligence and academic achievement among adolescents in kerman-iran. Journal of American Science, 8(9), 823-832.

Delors, J. (1996) La educación encierra un tesoro. [Informe a la UNESCO de la Comisión Internacional sobre la educación para el siglo XXI]. Santillana/Ediciones UNESCO.

Denham, S. A. (2006). Social-emotional competence as support for school readiness: What is it and how do we assess it?. Early education and development, 17(1), 57-89.

Durlak, J. A., Weissberg, R. P., Dymnicki, A. B., Taylor, R. D., \& Schellinger, K. B. (2011). The impact of enhancing students' social and emotional learning: A meta-analysis of school-based universal interventions. Child development, 82(1), 405-432.

Eisenberg, N., Fabes, R. A., \& Spinrad, T. L. (2007). Prosocial development. Handbook of child psychology, 3.

European Parliament and Council of the European Union. (2006). Recommendation of the European Parliament and of the Council of 18 December 2006 on key competencies for lifelong learning. Official Journal of the European Union. https://eur-lex.europa.eu/LexUriServ/LexUriServ.do?uri=OJ:L:2006:394:0010:0018:en:PDF

Farrington, C. A., Roderick, M., Allensworth, E., Nagaoka, J., Keyes, T. S., Johnson, D. W., \& Beechum, N. O. (2012). Teaching Adolescents to Become Learners: The Role of Non-cognitive Factors in Shaping School Performance--A Critical Literature Review. Consortium on Chicago School Research. 1313 East 60th Street, Chicago, IL 60637.

Ferragut, M., \& Fierro, A. (2012). Inteligencia emocional, bienestar personal y rendimiento acadé- mico en preadolescentes. Revista Latinoamericana de Psicología, 44(3), 95-104. 
Ghabanchi, Z., \& Rastegar, R. (2014). The correlation of IQ and emotional intelligence with reading comprehension. The Reading Matrix, 14(2), 135-144.

Graziano, P. A., Reavis, R. D., Keane, S. P., \& Calkins, S. D. (2007). The role of emotion regulation in children's early academic success. Journal of school psychology, 45(1), 3-19.

Gumora, G., \& Arsenio, W. F. (2002). Emotionality, emotion regulation, and school performance in middle school children. Journal of school psychology, 40(5), 395-413.

Haidt, J. (2003). The moral emotions. Handbook of affective sciences, 11(2003), 852-870.

Hanin, V., \& Van Nieuwenhoven, C. (2016). The influence of motivational and emotional factors in mathematical learning in secondary education. Revue Européenne de Psychologie Appliquée/European Review of Applied Psychology, 66(3), 127-138.

Hattie, J. (2008). Visible learning: A synthesis of over 800 meta-analyses relating to achievement. routledge.

Hattie, J., \& Yates, G. C. (2013). Visible learning and the science of how we learn. Routledge.

Hawkins, J. D., Kosterman, R., Catalano, R. F., Hill, K. G., \& Abbott, R. D. (2008). Effects of social development intervention in childhood 15 years later. Archives of Pediatrics \& Adolescent Medicine, 162(12), 1133-1141.

Hintsanen, M., Alatupa, S., Jokela, M., Lipsanen, J., Hintsa, T., \& Leino, M. (2012). Associations of temperament traits and mathematics grades in adolescents are dependent on the rater but independent of motivation and cognitive ability. Learning and Individual Differences, 22(4), 490-497.

Howse, R., Calkins, S., Anastopoulous, A., Keane, S., \& Shelton, T. (2003). Regulatory contributors to children's kindergarten achievement. Early Education and Development, 14, 101-120.

Ivcevic, Z., \& Brackett, M. (2014). Predicting school success: Comparing conscientiousness, grit, and emotion regulation ability. Journal of research in personality, 52, 29-36.

Izard, C., Fine, S., Schultz, D., Mostow, A., Ackerman, B., \& Youngstrom, E. (2001). Emotion knowledge as a predictor of social behavior and academic competence in children at risk. Psychological science, 12(1), 1823.

Jiménez-Morales, M.I., \& López-Zafra, E. (2013). Impacto de la inteligencia emocional percibida, actitudes sociales y expectativas del profesor en el rendimiento académico. Electronic Journal of Research in Educational Psychology, 11(29), 75-98.

Jolliffe, D., \& Farrington, D. P. (2006). Development and validation of the Basic Empathy Scale. Journal of adolescence, 29(4), 589-611.

Kalaycioglu, D. B. (2015). The Influence of Socioeconomic Status, Self-Efficacy, and Anxiety on Mathematics Achievement in England, Greece, Hong Kong, the Netherlands, Turkey, and the USA. Educational Sciences: Theory and Practice, 15(5), 1391-1401.

Kuo, Y. L., Casillas, A., Walton, K. E., Way, J. D., \& Moore, J. L. (2020). The intersectionality of race/ethnicity and socioeconomic status on social and emotional skills. Journal of Research in Personality, 84, 103905.

Lehne, M., Engel, P., Rohrmeier, M., Menninghaus, W., Jacobs, A. M., \& Koelsch, S. (2015). Reading a suspenseful literary text activates brain areas related to social cognition and predictive inference. PLOS One, 10(5), e0124550. 
Llorent, V. J., González-Gómez, A., Farrington, D. P. \& Zych, I. (2020). Social and emotional competencies and empathy as predictors of literacy competence. Psicothema: https://doi.org/10.7334/psicothema2019.106

Llorent, V.J. \& González-Gómez, A.L. (2020). Literacy competence and social and emotional competencies in Primary Education. Individual and ethnic-cultural factors. Revista Espacios 41 (6), https://www.revistaespacios.com/a20v41n06/20410608.html

López-González, L., \& Oriol, X. (2016). La relación entre competencia emocional, clima de aula y rendimiento académico en estudiantes de secundaria. Cultura y educación, 28(1), 130-156.

Loveless, T. (2015). Girls, boys, and reading. Brown Center Report on American Education, 3, 3-25.

Maná, A. (2014). Reading Literacy in Compulsory Secondary Education: An exploration of the difficulties in the use of information to answer questions/ La competencia lectora en la Educación Secundaria Obligatoria: descripción y dificultades del uso de información para responder preguntas. Cultura y Educación / Culture and Education, vol. 26, núm. (1), pp. 184-202.

Marks, G. N. (2008). Accounting for the gender gaps in student performance in reading and mathematics: evidence from 31 countries. Oxford Review of Education, 34(1), 89-109.

Martínez, I. P. (2017). Tiempos de resultados de aprendizaje. Avances en Supervisión Educativa, (26).

Masud, S., Mufarrih, S., Qureshi, N., Khan, F., Khan, S., \& Khan, N. (2019). Academic Performance in Adolescent Students: The Role of Parenting Styles and Socio-Demographic Factors-A Cross Sectional Study from Peshawar, Pakistan. Frontiers in psychology, 10, 2497.

Mavroveli, S., Petrides, K. V., Sangareau, Y., \& Furnham, A. (2009). Exploring the relationships between trait emotional intelligence and objective socioes en un g outcomes in childhood. British Journal of Educational Psychology, 79(2), 259-272.

Miñano, P., \& Castejón, J. L. (2011). Variables cognitivas y motivacionales en el rendimiento académico en Lengua y Matemáticas: un modelo estructural. Revista de psicodidáctica, 16(2), 203-230.

Nasaescu, E., Marín-López, I., Llorent, V.J., Ortega-Ruiz, R., \& Zych, I. (2018). Abuse of technology in adolescence and its relation to social and emotional competencies, emotions in online communication, and bulling. Computer in Human Behavior, 88, 144-120. doi: 10.1016/j.chb.2018.06.036

Oberle, E., Schonert-Reichl, K. A., Hertzman, C., \& Zumbo, B. D. (2014). Social-emotional competencies make the grade: Predicting academic success in early adolescence. Journal of Applied Developmental Psychology, 35(3), 138-147.

OECD (2003). The PISA 2003 assessment framework. Mathematics, reading, science and problem solving knowledge and skills. Paris: OECD.

OECD (2015). Skills for social progress: The power of social and emotional skills. OECD Publishing. Paris: OECD.

OECD (2016). PISA 2015 Assessment and Analytical Framework: Science, Reading, Mathematics and Financial Literacy. Paris: OECD.

Palomera, R., Gil-Olarte, P., \& Brackett, M.A.(2006). ¿Se perciben con IE los docentes? Posibles consecuencias sobre la calidad educativa. Revista de Educación, 341, 687-703.

Panayiotou, M., Humphrey, N., \& Wigelsworth, M. (2019). An empirical basis for linking social and emotional learning to academic performance. Contemporary Educational Psychology, 56, 193-204. 
Parhiala, P., Torppa, M., Vasalampi, K., Eklund, K., Poikkeus, A.-M., \& Aro, T. (2018). Profiles of school motivation and emotional well-being among adolescents: Associations with math and reading performance. Learning and Individual Differences, 61, 196-204. doi:10.1016/j.lindif.2017.12.003

Puccioni, J. (2015). Predictors of reading achievement: Time on reading instruction and approaches to learning. Literacy Research: Theory, Method, and Practice, 64(1), 249-266.

Roegiers, X. (2016). Marco conceptual para la evaluación de competencias. Oficina Internacional de Educación de la Unesco. París.

Roseth, C. J., Johnson, D. W., \& Johnson, R. T. (2008). Promoting early adolescents' achievement and peer relationships: The effects of cooperative, competitive, and individualistic goal structures. Psychological bulletin, 134(2), 223.

Rosselli, M., Matute, E., and Ardila, A. (2006). Predictores neuropsicológicos de la lectura en español. Revista de Neurología, 42, 202-210.

Sandstrom, M. J., \& Cillessen, A. H. (2003). Sociometric status and children's peer experiences: Use of the daily diary method. Merrill-Palmer Quarterly (1982-), 427-452.

Seider, S., Gilbert, J. K., Novick, S., \& Gomez, J. (2013). The role of moral and performance character strengths in predicting achievement and conduct among urban middle school students. Teachers College Record, 115(8), n8.

Sewasew, D., \& Koester, L. S. (2019). The developmental dynamics of students' reading self-concept and reading competence: Examining reciprocal relations and ethnic-background patterns. Learning and Individual Differences, 73, 102-111.

Sklad, M., Diekstra, R., Ritter, M. D., Ben, J., \& Gravesteijn, C. (2012). Effectiveness of school-based universal social, emotional, and behavioral programs: Do they enhance students' development in the area of skill, behavior, and adjustment?. Psychology in the Schools, 49(9), 892-909.

Stevens, T., Olivárez Jr, A., \& Hamman, D. (2006). The role of cognition, motivation, and emotion in explaining the mathematics achievement gap between Hispanic and White students. Hispanic Journal of Behavioral Sciences, 28(2), 161-186.

Suárez-Álvarez, J., Fernández-Alonso, R., \& Muñiz, J. (2014). Self-concept, motivation, expectations, and socioeconomic level as predictors of academic performance in mathematics. Learning and Individual Differences, 30, 118-123.

Tangney, J. P. (1991). Moral affect: the good, the bad, and the ugly. Journal of personality and social psychology, 61(4), 598.

Trentacosta, C. J., \& Izard, C. E. (2007). Kindergarten children's emotion competence as a predictor of their academic competence in first grade. Emotion, 7(1), 77.

UNESCO (2016). Education 2030: Incheon declaration and framework for action for the implementation of sustainable development goal 4: Ensure inclusive and equitable quality education and promote lifelong learning opportunities for all. Ediciones Unesco.

Villavicencio, F. T., \& Bernardo, A. B. (2016). Beyond math anxiety: Positive emotions predict mathematics achievement, self-regulation, and self-efficacy. The Asia-Pacific Education Researcher, 25(3), 415-422. 
Walshaw, M., \& Brown, T. (2012). Affective productions of mathematical experience. Educational Studies in Mathematics, 80(1-2), 185-199.

Wu, L., Valcke, M., \& Van Keer, H. (2019). Factors associated with reading comprehension of secondary school students. Educational Sciences: Theory \& Practice, 19(4), 34-47.

Zych, I., Beltrán-Catalán, M., Ortega-Ruiz, R., \& Llorent, V. J. (2018a). Competencias sociales y emocionales de adolescentes involucrados en diferentes roles de bullying y cyberbullying. Revista de Psicodidáctica, 23(2), 86-93. http://dx.doi.org/10.1016/j.psicod.2017.12.001

Zych, I., Gómez-Ortiz, O., Touceda, L. F., Nasaescu, E., \& Llorent, V. J. (2019). Parental Moral Disengagement Induction as a Predictor of Bullying and Cyberbullying: Mediation by Children's Moral Disengagement, Moral Emotions, and Validation of a Questionnaire. Child Indicators Research, 1-19. https://doi.org/10.1007/s12187-019-09670-2

Zych, I., Ortega-Ruiz, R., Muñoz-Morales, R., \& Llorent, V. J. (2018b). Dimensions and psychometric properties of the Social and Emotional Competencies Questionnaire (SEC-Q) in youth and adolescents. Revista Latinoamericana de Psicología, 50(2), 98-106. http://dx.doi.org/10.14349/rlp.2018.v50.n2.3

Esta obra está bajo una Licencia Creative Commons Attribución-NoCommercial 4.0 International

\section{(cc) EY-NC}

